\title{
Education Services based on Quality Assurance and Customer Satisfaction of Private Colleges in Central Sulawesi, Indonesia
}

\author{
Syamsuddin $\mathrm{R}^{1^{*}}$, Syamsul Bachri ${ }^{2}$, Saharuddin Kaseng ${ }^{2}$, Maskuri Sutomo ${ }^{2}$ \\ ${ }^{1}$ Postgraduate Program, Tadulako University, Indonesia \\ ${ }^{2}$ Faculty of Economic, Tadulako University, Indonesia
}

\begin{abstract}
DOI: $\underline{10.36348 / \text { sjef.2020.v04i06.011 }}$
| Received: 05.06.2020 | Accepted: 13.06.2020 | Published: 16.06.2020
\end{abstract}

*Corresponding author: Syamsuddin $\mathrm{R}$

\section{Abstract}

The purpose of this study was to find out the description of education services based on quality assurance and customer satisfaction of private colleges in Central Sulawesi Province. It was a descriptive research, conducted at private colleges in Central Sulawesi Province. The population of the study was all undergraduate students who were registered and active in the B accredited study program on private colleges in the Regencies/Cities of Central Sulawesi Province in 2017. The variables were the quality of education/learning based on quality assurance and customer satisfaction toward education services in those colleges. The results of the study showed that students' perceptions about the quality of education services obtaining a total average score of 4.01 (good category). Customer satisfaction had a mean value of 4.02, indicates that the educational services provided were felt satisfactory. The quality of education/learning based on quality assurance was perceived well by students, in accordance with the quality standards of accreditation B obtained by study programs. The value or benefits of education/learning services are also good and satisfying so that most students feel trustworthy and loyal to the institutions and study programs of higher education.

Keywords: Quality of education, customer satisfaction, undergraduate students, private colleges.

Copyright @ 2020: This is an open-access article distributed under the terms of the Creative Commons Attribution license which permits unrestricted use, distribution, and reproduction in any medium for non-commercial use (NonCommercial, or CC-BY-NC) provided the original author and source are credited.

\section{INTRODUCTION}

In Indonesia, the service sector, including higher education services, also increased rapidly. In just a decade, the overall service share to GDP increased from 44 percent to more than 50 percent, while the share of employment rose at a similar rate until in 2010, there were at least less than 50 percent of all jobs [1]. Whereas the higher education service sector, particularly the higher education service sector managed by the non-governmental which is commonly referred to as private tertiary education, in the period 2012-2017 continued to experience a significant increase both in the number of institutions, as well as the number of students and education personnel (lecturers). The changing paradigm of society towards education, which is getting more influential on education as an investment, has now conditioned all education sectors to become institutions that provide a beneficial economic return. Higher education must be able to produce competent graduates who reliable in competition and able to provide reinforcement individually for the dissemination of knowledge, so educational institutions must be proactive and become efficient and effective institutions [2].
For higher education service users, the emergence of new tertiary institutions in the market will benefit the community, especially prospective students, because the public has more alternative choices, so they can be more selective in choosing universities that offer educational services according to their needs, desires, and its importance. But on the other hand, too many choices can mislead prospective students in making decisions, because choosing a higher education institution is not a simple thing, because it is a longterm decision that is closely related to one's personal life, future, social life, economic problems, work or even family life and the lives of others. But on the other hand, too many choices may mislead prospective students in making decisions, because choosing a higher education institution is not a simple thing, it needs a long-term decision that is closely related to one's personal life, future, social life, economic problems, work or even family life and the lives of others. The process of selecting the higher education in large numbers is not easy because it is an important and complex decision for students, not only in economic terms but also a long-term decision that affects their future lives [3]. 
In the context of tertiary education, the quality of educational services and the fees paid as a sacrifice must be proportional to the quality of educational services received as a value felt by the customer (student). Therefore, the creation and delivery of superior customer value are essential in creating sustainable profits in the highly competitive international education market. The quality of educational services is recognized as a critical performance measure for excellence in education and is a crucial strategic variable for universities as providers of educational services, with lasting influence on the institutions and students it serves [4].

In a college, where students are the main customers, student satisfaction must always be considered by universities due to the intense competition between universities, the spirit of internalization, high expectations of students, increased tuition fees, classification of education as valuable services [5]. Competition is increasingly competitive in educational institutions, and current market forces need to adopt market orientation strategies that differentiate their offerings from their competitors by providing superior quality services [4]. Therefore, demands on the quality of education are getting stronger, especially when there is a change in the macro paradigm of the influence from dynamic globalization, which tends to change and demands of a more transparent style of economic logic.

The study aimed to find out the description of education services based on quality assurance and customer satisfaction of private tertiary educational institutions in Central Sulawesi Province.

\section{METHODS}

This study was descriptive research. It was conducted at private universities/colleges which were within the supervision of the Indonesia Directorate of Higher Education which organizes and manages the undergraduate level education and implements quality assurance programs located in Central Sulawesi
Province, with the number of active students was 27.586 persons in 22 private colleges consisting of 7 Universities and 15 academies.

The population of this research was all undergraduate students who are registered and active in the B accredited Study Program of Private Higher Educational Institutional in the Regency / Cities of Central Sulawesi Province in 2017, which are 10.867 persons. Based on the total student population, the number of research samples was 200 persons.

The quality of education/learning based on quality assurance is the quality based on standards (internal quality). It is the standard suitability run by tertiary educational institutions and the quality based on the perceptions and expectations of the undergraduate student (external quality) on eight quality standards or dimensions of education/learning services plus the quality of accreditation results, namely the quality of lecturers and education personnel, the quality of learning facilities and infrastructure, the quality of tuition funding, the quality of learning content, the quality of learning processes, the quality of learning assessment, the quality of graduate competency standards, the quality of learning management standards, and the quality of accreditation.

Customer satisfaction of educational services at colleges is a long-term attitude resulting from the evaluation of student customers from the various results and experiences of students from perceived services with the expected service [6]. The measurement dimensions of customer satisfaction used measurement dimensions developed Zeithaml dan Bitner, 2017 consisting of service quality, product quality, cost, situation factors, and personal factors [7].

Data analysis was descriptive analysis using the SPSS application presented in the form of tables and descriptions of each table.

\section{RESULTS AND DISCUSSIONS}

Table-1: Characteristics of respondents

\begin{tabular}{|l|l|l|}
\hline Characteristics & n & \% \\
\hline Sex & & \\
Male & 91 & 44 \\
Female & 116 & 56 \\
\hline Age & & \\
$<21$ years & 151 & 73 \\
$21-24$ years & 30 & 14 \\
$\geq 25$ years & 26 & 13 \\
\hline Marital status & & \\
Unmarried & 176 & 85 \\
Married & 31 & 15 \\
\hline Origin of High School & & \\
Academic High School & 139 & 67 \\
Vocational High School & 63 & 31 \\
Others & 2 & 2 \\
\hline
\end{tabular}


Table-1 shows female attending the private universities of Central Sulawesi Province was more than male. This, indicating that the interest of women in continuing education to the college level was increasing even to those areas. The high importance of women continuing education in college may be due to the population structure is indeed more women. Still, it may also be due to the presence of gender equality that gives the same opportunity is not discriminatory to men and women in the activities of the community. The student's age illustrates that the students attending private colleges were not all new high school graduates. But some of them were graduates a few years earlier, and even some had been working. Based on the marital status, about 31 respondents $(15 \%)$ were married, and 176 respondents $(85 \%)$ were unmarried. The background of Academic High School dominated private college students in Central Sulawesi Province. Also, these kinds of universities in Central Sulawesi are enthused by high school graduates with a vocational high school background and other schools that are equivalent to high school grades (Table 1).

Table-2: Respondents based on specialization aspects

\begin{tabular}{|l|l|l|}
\hline Aspects of Specialization & n & \% \\
\hline Research for college & & \\
Own will & 169 & 82 \\
Follow friends & 3 & 1 \\
Parental encouragement & 10 & 5 \\
Work requirements & 25 & 12 \\
\hline Campus attractiveness & & \\
Famous & 8 & 4 \\
Needed by the World of Work & 48 & 23 \\
Accreditation & 79 & 38 \\
Reachable & 58 & 28 \\
College student activity organizations & 14 & 7 \\
\hline
\end{tabular}

Table-2 shows that the interest of college students in non-state colleges in Central Sulawesi Province was driven by their own volition and because of work demands. This means that the interest of students in college is motivated by the motivation to improve their qualifications in meeting work demands, which are required by both recipients and private institutions to have a minimum education equivalent to the undergraduate level. The most significant factor in determining student interest in choosing private colleges in Central Sulawesi Province was the accreditation factor, which was about 79 persons (38 $\%)$. In this study, the focus was on the accredited study program B. The second most significant factor was the campus location factor that is easily reached, which was about 58 persons $(28 \%)$. The third factor was the factor of work needs, which was about 48 persons $(23 \%)$. The next factor was the college student activity organizations factor, which was about 14 persons $(7 \%)$.

Table-3: Respondents based on aspects of funding and sources of tuition funds

\begin{tabular}{|l|l|l|}
\hline Aspects of Funding and Sources of Tuition Funds & $\mathbf{n}$ & $\%$ \\
\hline Employment status & 156 & 75.00 \\
Not yet working & 51 & 25.00 \\
Working & & \\
\hline College Financing Sources & 51 & 25.00 \\
Self-financing & 150 & 72.00 \\
Parents & 6 & 3.00 \\
Scholarship & & \\
\hline Tuition suitability & 189 & 91.00 \\
Suitable & 19 & 9.00 \\
Not suitable & & \\
Status of student housing & 32 & 15.00 \\
Own house & 81 & 39.00 \\
Parent's house & 76 & 37.00 \\
Boarding house & 18 & 9.00 \\
Stay with family & & \\
\hline
\end{tabular}

Table-3 shows that there were 51 undergraduate students $(25 \%)$ who were working and about 156 undergraduate students (75 percent) who were not working. The working students are certainly easier to finance compared to those who are not yet working. However, the problem for working students is the lecture time so that it can hamper the completion of student studies and sometimes students fail to continue their education due to work demands. So there needs to be a solution to overcome this time problem, including 
adjusting the lecture time for students who are already working without reducing the education quality itself. Based on this condition, then some private universities take the policy to conduct lectures at night, to accommodate students who have worked. The funding source of college students in private universities in Central Sulawesi province as much as 150 respondents (72\%) were from parents and 51 persons (25 percent) of their own costs, and about 6 persons ( $3 \%$ ) of student fellowship. That illustration shows that the source of private college student funding in Central Sulawesi Province was still mostly sourced from parent financing. Thus the role of income and employment of students' parents also determines the sustainability of college students.

The aspect of tuition suitability shows that the majority of respondents who study at private colleges in Central Sulawesi Province were 189 persons (91\%), stating that tuition was paid accordingly. Only about 19 respondents $(9 \%)$ said that it was not appropriate. It means that the tuition fee of private colleges in Central Sulawesi Province was considered to be appropriate and affordable by students. The residential status aspect shows that the majority of students living at home no longer need to pay additional fees, i.e., as many as 81 students $(39 \%)$ lived in the parents home, 32 students $(15 \%)$ who lived in their own homes, and 18 students (9\%) stayed with their family. In contrast, students who lived in boarding houses were about 76 persons (37\%) who had to pay a high additional cost. This situation will undoubtedly burden the parents, so it greatly affects the completion of the study because of inadequacy funds.

Quality of Education Services Based on Quality Assurance

Table-4: Variable of frequency distribution quality of education services based on quality assurance of higher education institutions in the Central Sulawesi Province

\begin{tabular}{|c|c|c|c|c|c|c|c|}
\hline \multirow[t]{3}{*}{ Dimension } & \multicolumn{6}{|c|}{ Average Frequencies } & \multirow[t]{3}{*}{ Mean } \\
\hline & \multicolumn{2}{|c|}{ Very Good (5) } & \multicolumn{2}{|c|}{$\begin{array}{l}\text { Good } \\
\text { (4) }\end{array}$} & \multicolumn{2}{|c|}{$\begin{array}{l}\text { Quite Good } \\
\text { (3) }\end{array}$} & \\
\hline & $\mathbf{F}$ & $\%$ & $\mathbf{F}$ & $\%$ & $\mathbf{F}$ & $\%$ & \\
\hline Quality of lecturers and educational staff & 52 & 25.12 & 108 & 52.17 & 47 & 22.71 & 4,02 \\
\hline Quality of learning facilities and infrastructure & 61 & 29.51 & 91 & 43.88 & 55 & 26.61 & 4,03 \\
\hline Quality of learning funding & 54 & 26.21 & 97 & 46.98 & 56 & 26.81 & 3,99 \\
\hline Quality of learning content & 55 & 26.57 & 104 & 50.24 & 48 & 23.19 & 4,03 \\
\hline Quality of learning process & 61 & 29.47 & 89 & 42.89 & 57 & 27.64 & 4,02 \\
\hline Quality of learning assessment & 55 & 26.35 & 96 & 46.51 & 56 & 27.14 & 3,99 \\
\hline Quality of learning management & 56 & 26.85 & 99 & 47.69 & 53 & 25.47 & 4,01 \\
\hline Quality of graduates' competencies & 52 & 25.28 & 112 & 54.11 & 43 & 20.61 & 4,05 \\
\hline Quality of accreditation results & 57 & 27.54 & 105 & 50.89 & 45 & 21.58 & 4,06 \\
\hline Average quality of education based on quality assurance & 57 & 27.54 & 97 & 46.86 & 53 & 25.60 & 4,01 \\
\hline
\end{tabular}

Table-4 shows that students' perceptions about the quality of education services obtained an average total score of 4.01 (good category). Overall, the indicator of the quality dimension of quality assurance education services seems to be valued well by students and even most of the dimensions are above the mean value of the variable. Indicator dimensions of the accreditation quality results had the highest mean value of 4.06. Then followed by the dimensions of graduate competency quality with a mean value of 4.05 ; the dimensions of the quality of learning facilities and infrastructure and the quality dimension of learning content with a mean value of 4.03; the quality dimensions of the learning process with a mean value of 4.02; the quality dimensions in the management of perceived learning have the same mean value of the variable mean which is 4.01 .

The service quality starts with the customer's needs and ends on the customer's feeling of the service received. The quality of service referred to in this study is the education quality based on quality assurance namely the improvement of education services carried out continuously through the implementation of internal and external quality assurance (accreditation) for achieving a standard of higher education quality that has been set nationally and by the college.

Customer perception of the service quality is a comprehensive assessment of the advantages of service received and felt by customers [8]. Students' perceptions about the quality of education services based on quality assurance as well as the value, satisfaction, trust, and loyalty of student toward the educational services at institutions and/or study programs of private tertiary institutions in Central Sulawesi Province are students assessments involved in the education process about the quality of educational services (academic quality, administrative quality, and relationship quality) received by students from those institutions/study programs. Service assessment is done by comparing the perceived service with expected service [9]. 
Indicators of the dimensions of the education services quality that were below the mean value of the variable and simultaneously occupied the lowest position are the dimensions of the quality of learning assessment and the dimensions of the quality of learning financing with a mean value of 3.99 each. The low perception of students in these two dimensions can also be seen in several supporting indicators of their dimensions. It shows that although the education services quality delivered by higher education institutions and study programs is perceived well by most students, there are still some students who feel that the quality of education services obtained is still not optimal or still not good enough. This situation may have an unfavorable impact on the creation of value, satisfaction, trust, and loyalty, of students in those colleges [10].

Meanwhile, the dimension of accreditation quality perceived as the highest mean was 4.06 (good category). This matter shows the improvement of the education services quality conducted by private colleges and study programs in Central Sulawesi Province through the implementation of internal quality assurance is considered good so that it gets an accreditation value $B$ from the National Accreditation Board for Higher Education of Indonesia. Thus, the quality of education services at institutions and study programs is seen from internal quality (quality based on standards), and external quality (quality based on student perceptions) assessed and felt to have good quality, but not yet very good, so efforts are still needed to improve the quality of services, especially in the learning process which is the core of education services in an educational institution including tertiary institutions.

Variables of Customer Satisfaction

Table-5: Average frequency distribution of variable customer satisfaction values of private colleges in Central Sulawesi Province

\begin{tabular}{|l|l|l|l|l|l|l|l|}
\hline \multirow{2}{*}{ Dimension } & \multicolumn{4}{|l|}{ Average frequencies } & \multirow{2}{*}{ Mean } \\
\cline { 2 - 7 } & Very satisfied (5) & \multicolumn{2}{|l|}{ Satisfied (4) } & \multicolumn{2}{l|}{ Quite satisfied (3) } & \\
\cline { 2 - 7 } & $\mathrm{F}$ & $\mathbf{\%}$ & $\mathbf{F}$ & $\mathbf{\%}$ & $\mathbf{F}$ & $\mathbf{\%}$ & \\
\hline Quality of service & 54 & 25,85 & 107 & 51,79 & 46 & 22,37 & 4,03 \\
\hline Quality of product & 53 & 25,51 & 105 & 50,82 & 49 & 23,67 & 4,02 \\
\hline Fees & 54 & 25,85 & 105 & 50,49 & 49 & 23,67 & 4,02 \\
\hline Situational factors & 50 & 24,16 & 104 & 50,00 & 53 & 25,85 & 3,98 \\
\hline Personal factors & 54 & 26,09 & 101 & 48,95 & 52 & 24,96 & 4,01 \\
\hline Average customer satisfaction & $\mathbf{5 3}$ & $\mathbf{2 5 , 6 0}$ & $\mathbf{1 0 5}$ & $\mathbf{5 0 , 7 2}$ & $\mathbf{4 9}$ & $\mathbf{2 3 , 6 7}$ & $\mathbf{4 , 0 2}$ \\
\hline
\end{tabular}

Table-5 shows that the respondents' satisfaction variable had a mean value of 4.02 , indicates that the educational services provided by private institutions in Central Sulawesi Province to students were felt to be satisfactory. The same condition was also felt in all dimensions, supporting indicators of students' satisfaction variable dimensions, which were perceived as satisfying categories. The highest mean value was 4.03 in the service quality, the product quality and fees hade a mean value of 4.02 , the personal factor reached a mean value of 4.01, and the situation factor dimension hit the lowest mean value of 3.98

Customer Satisfaction at tertiary institutions is defined as a long-term attitude that results from evaluations of students from the various results and experiences of students from educational services that are received or felt with the expected service [11]. Reflected by the dimensions of service quality, product quality, fees, situational factors, personal factors [7].

Table-5 shows that the quality of education services delivered by private tertiary institutions and study programs in Central Sulawesi Province on several indicators of perceived dimensions provides a high level of satisfaction with a mean value higher than the average variable and some are perceived by the mean value is lower than the average of the variable or is considered to be less than optimal in supporting the variable. Therefore, the quality of education services still needs to be improved, particularly on indicators that are perceived to have not maximally met expectations, which cause students to feel less satisfied, so that education services received are felt to be able to provide better grades and satisfy students. So that students are more trusting and willing to establish longterm relationships with institutions and study programs in higher education.

\section{CONCLUSIONS}

The education quality based on quality assurance of private higher education in Central Sulawesi Province is perceived well by students, in accordance with the quality standards or the results of accreditation $\mathrm{B}$ obtained by study programs. The value or benefits of education services are also good and satisfying so that most students feel trustworthy and loyal to the institutions and study programs of higher education.

\section{REFERENCES}

1. Manning, C. A. (2012). 'Perdagangan dan pekerjaan di sektor jasa di Indonesia: ringkasan 
kebijakan'. International Labour Organization (ILO),

http://www.ilo.org/jakarta/whatwedo/publications/ WCMS_185239/lang--en/index.htm (accessed Jun. 05, 2020).

2. Soemantri, B. S. (2004). The Indonesian Higher Education 2003-2010. Jakarta: Directorate General of Higher Education.

3. Duarte, P. O., Alves, H. B., \& Raposo, M. B. (2010). Understanding university image: a structural equation model approach. International review on public and nonprofit marketing, 7(1), 21-36.

4. Thomas, S. (2011). What drives student loyalty in universities: An empirical model from India. International Business Research, 4(2), 183.

5. Ling, K. C., Chai, L. T., \& Piew, T. H. (2010). The 'inside-out'and 'outside-in'approaches on students' perceived service quality: An empirical evaluation. Management Science and Engineering, 4(2), 1-26.

6. Elliott, K. M., \& Shin, D. (2002). Student satisfaction: An alternative approach to assessing this important concept. Journal of Higher Education policy and management, 24(2), 197209.
7. Zeithaml, V., Bitner, M. J., \& Gremler, D. (2017). Services Marketing: Integrating Customer Focus Across the Firm. New York: McGraw-Hill.

8. Permana, A. W., Suardika, N., Sujana, W., \& Yuesti, A. (2019). Analysis of service quality and value effect on patient satisfaction and its effect on loyalty of hospital patients in hospital and children of pucuk permata hati. International Journal of Contemporary Research and Review, 10(2), 21255-21266.

9. Álvarez-García, J., González-Vázquez, E., RíoRama, D., de la Cruz, M., \& Durán-Sánchez, A. (2019). Quality in Customer Service and Its Relationship with Satisfaction: An Innovation and Competitiveness Tool in Sport and Health Centers. International Journal of Environmental Research and Public Health, 16(20), 3942.

10. Pradhan, N. S., Su, Y., Fu, Y., Zhang, L., \& Yang, Y. (2017). Analyzing the effectiveness of policy implementation at the local level: a case study of management of the 2009-2010 Drought in Yunnan Province, China. International Journal of Disaster Risk Science, 8(1), 64-77.

11. Hasan, H. F. A., Ilias, A., Rahman, R. A., \& Razak, M. Z. A. (2008). Service quality and student satisfaction: A case study at private higher education institutions. International Business Research, 1(3), 163-175. 